\title{
Organizational Climate as Determinant of Sustainable Peace Culture in Higher Institutions in Cross River State, Nigeria
}

\author{
*Dr. C. P. Akpan \\ Dr. (Mrs) S. Ekere
}

Department of Educational Administration \& Planning, Faculty of Education, University of Calabar 540004, Calabar, Nigeria; Email: drcpakpan@yahoo.com

\section{Doi:10.5901/mjss.2016.v7n3p467}

\section{Abstract}

The purpose of the study was to find out the extent to which organizational climate predicted sustainable peace culture in higher institutions in Cross River State, Nigeria. A survey research design was used and a sample of 500 lecturers randomly selected from 4 higher institutions was used for the study. Two hypotheses guided the study. Data were collected using a questionnaire titled "Organizational Climate and Sustainable Peace Culture Questionnaire" (OCSPCQ). Data were analyzed using multiple regressions and t-test statistics. The result of the study revealed that organizational climate had a significant effect on sustainable peace culture in higher institutions. There was a significant correlation between the joint predictor variables and sustainable peace culture. The organizational climate variables made significant relative contributions to the determinacy of sustainable peace culture in higher institutions. Premised on the findings of the study, it was recommended that institutional administrators should encourage a healthy interpersonal relationship and create a disciplined school environment to promote sustainable peace culture in higher institutions.

Keywords: Organizational Climate, Determinants, Peace Culture, Higher Institutions, Nigeria.

\section{Introduction}

In any work organization, an atmosphere of peace and harmony is a pre-requisite for achievement of set goals and objectives. In the school organization, an atmosphere of peace is needed for effective teaching and learning. However, higher institutions in Nigeria and in Cross River State in particular appear to be devoid of a culture of peace. This is evident in students' frequent crisis resulting in vandalism, staff protracted strikes and cult activities which have become the order of the day in higher institutions across the country. Peace is a condition in which there is no social conflict or antagonism and individuals and groups are able to meet their needs and expectations (Okeke\&Emenalo, 2010). According to Oke (2006), peace is a process involving activities that are directly or indirectly linked to increase development and reduce conflict both within specific societies and in the wider international community. This means that peace is the absence of social violence and crisis. It refers to tranquility of order. In the school organization, peace is a situation where the school environment is calm, orderly and stable and all the subsystems or units are attuned, reconciled and harmonized to work as a team for the success of the school. On the other hand, a culture of peace refers to the values, attitudes and behavioural patterns emanating from non-violence and respect for the human rights. It refers to a culture where values, norms and ways of behaving encourage the non-violent resolution of conflicts and tackle the root causes of these conflicts (Rivera, 2009).

In the context of this paper, peace culture is viewed as the practices, norms, activities and values that promote harmonious relationship and peaceful co-existence among administrators, staff and students in higher institutions. It refers to those practices that give institutions their identities and standards for expected behavior thereby preventing violence and violent conflicts. Rivera (2009) emphasizes that building a culture of peace in any organization revolves around participative management, tolerance, gender equality, respects for human rights, open communication and peace education. Similarly, EDUCA Peace Education Project (2003) maintains that to promote peace culture in the school community emphasis should be on effective management and appreciation for diversity (respect, anti-racism and antidiscrimination), peaceful conflict resolution (anger-management, non-violent language and behavior) and group participation and collaboration.

However, the extent to which peace culture can be sustained in a higher institution depends greatly on the organizational climate of the institution. In other words, the school climate can promote or mar sustainable peace culture 
in higher institutions. The organizational climate of a school is a set of internal characteristics that distinguishes one school from another and influences the attitude, actions and behaviors of school members (administrators, teachers, nonteaching staff and students). According to Osman (2012), it is a reflection of organizational structure and this gives a school its unique personality. He further states that effective schools create and maintain climates that are comfortable, pleasant and orderly. Such climates consistently enhance high expectations of staff and students and promote a culture of peace in the schools. Institutional administrators need to work towards improving the organizational (school) climate and conditions to encourage a culture of peace through maintenance of cordial relationship, team work and free flow of communication, good leadership, discipline and enforcement of institutional policies. Forehand and Likert cited in Peretomode (1999) identify the determinants of organizational climate to include the size and structure of the organization, leadership style, communication network, concern for employees' welfare, organizational policy, technological adequacy, characteristics of members, motivation and values. The Western Alliance for the study of school climate (2004) identified the following as components of organizational climate that can promote peace culture in school.

Appearance and physical facilities

Faculty relations

Students' interactions

Leadership/decision making

Disciplined environment

Learning environment

Attitude and culture

School-community relations

These components of the school climate depict that school climate embraces the physical, social and psychological aspects of the school environment that can foster and sustain peace culture in our higher institutions. The organizational climate variables considered in this study therefore, include leadership, communication pattern, physical facilities, discipline and interpersonal relationship.

The idea of organizational climate and a culture of peace in our higher institutions become essential because of the frequent crisis and violence in our schools and in the society. Fostering and promoting peace culture in our higher educational institutions through effective management of school climate is essential for students' academic performance and achievement, self-esteem, confidence and reducing the rate of violence and conflicts (Furman, 2004). Researchers have pointed out that promoting peace culture in schools could positively lead to higher quality of good citizens (Shield, 2004; Furman \& Grunewald, 2003). Karcher (2002) and Goldstein, Young and Boyd (2008) have shown in their researches that positive school climate is associated with reduced aggression and violence.

Although researches have been carried out on the relationship between organizational climate and students academic performance and teachers job effectiveness, but little or no work has been done on organizational climate and sustainable peace culture in higher institutions in Nigeria and in Cross River State in particular. It is against this background that the researcher was motivated to investigate organizational climate as determinant of sustainable peace culture in higher institutions in Cross River State of Nigeria.

\section{Statement of the Problem}

The issues of violent demonstrations by students coupled with incessant strike actions by lecturers in higher institutions have become a matter of serious concern. This has been attributed in part, to lack of a culture of peace in our institutions of higher learning as a result of ineffective management of organizational climate by institutional administrators. In some higher institutions, the leadership styles of the administrators are not participatory. There is lack of open communication. The indigene/non-indigene dichotomy has strongly permeated the management of many higher institutions in Nigeria, thereby creating grounds for conflicts that can jeopardize effective teaching and learning. In some institutions the schoolcommunity relations and interpersonal relationship is not cordial, while in others, draconian policies, rules and regulations are imposed on staff and students which in an attempt to resist may result in conflict. Hence, a culture of peace becomes a far cry. At this point therefore, it becomes pertinent to raise the question "How does organizational climate relate to sustainable peace culture in higher institutions?" This study seeks to provide answer to this question?

\section{Purpose of the Study}

The purpose of this study is to find out

1. The extent to which organizational climate (Leadership, communication, physical facilities, discipline and inter- 
personal relationship) predicts sustainable peace culture in higher institutions.

2. Determine the relative contribution of each component of organizational climate to sustainable peace culture in higher institutions.

\section{Hypotheses}

$\mathrm{HO}_{1}$ : Organizational climate does not significantly predict sustainable peace culture in higher institutions.

$\mathrm{HO}_{2}$ : There is no significant relative contribution of each of the components of organizational climate to sustainable peace culture in higher institutions.

\section{Literature Review}

Although research on the impact of organizational climate on promoting sustainable peace culture has not received much attention in schools in Cross River State of Nigeria, effort is made to review related literature. Organizational climate refers to the physical and psychological aspects of the school that are more susceptible to change and that provide the preconditions necessary for teaching and learning to take place. School climate is evident in the feelings and attitudes about a school as expressed by students, teachers, staff and parents. That is, the way students and staff feel about being in school each day (Gonder \& Hymes, 1994). Howand, Howell and Brainard (1987) in their study reported eight indicators of school climate that could foster a culture of peace in educational institutions. These included respect, caring, high morale, opportunities for input, continuous academic and social growth, school renewal, cohesiveness and trust. The institutional administrators have roles to play to ensure that staff and students are treated with respects and that they can trust each other and work together as partners in progress. Respect and trust are two important variables that can bind workers together and make them to work as a team for the success of the school. Cohesiveness suggests that school members should be made to feel a sense of belonging to the school. This would result in team spirit. This could be achieved through the principle of participative leadership. Osman (2012) in his study showed that leadership as a component of school climate significantly correlated with culture of peace in school.

According to the researcher, the way teachers and students feel about the school and themselves is a direct result of the leadership patterns and styles of school administrators. Through their leadership, administrators should provide a belief in people, positive reinforcement, high expectations, job and role diversity and celebrations of good performance (Osman, 2012).

In an earlier study by Remondini (2001), it was found that a significant relationship existed between leadership styles and organizational climate for supportive principal behavior and intimate teacher behavior. This means that leadership style can influence the behavior of both teachers and their school principals. This finding was in agreement with the work of Oredein (2006) which reported that the quality of work and learning in school depend to a large extent on the school principals' capacities, leadership styles and organizational climate of the school. Thus, the idea of organizational climate provides an understanding of how the different leadership styles impact on members of organization, the work achieved by it and the health of it (Aksu, 1994). The attitude of individuals is an important factor in educational institutions where human components have the greatest importance (Gul, 2008).

Therefore, the quality of attitudes has a great role not only on the mutual relations and the interactions, but also in creating a peaceful working environment and harmony for effective job performance (Taymaz, 2003).

Researchers have shown that interpersonal relationship which is also an organizational climate factor promotes a culture of peace in schools. Sweeney (1992) in a study reported that the level of interpersonal relationship significantly influence sustainable peace culture in work organizations. This suggests that a cordial interpersonal relationship in school is necessary for a harmonious and peaceful work environment. In other words, a positive school climate makes a difference in creating the right environment for peace to strife. This finding was in consonance with the research report of Merger-Adams and Conner (2008) which found that a healthy organizational climate significantly influence school members' attitude towards a culture of peace and correlated significantly with decreased students' absenteeism.

Furthermore, research had indicated that school climate influenced the beliefs, values and actions of teachers and students towards promoting a peaceful culture and critical to effective risk prevention (Berkowitz \& Bier, 2006). In a related study, Wang, Selman, Dishion and Stormshak (2010) found that in schools where students perceived a better structured school administration, school discipline and more positive student-teacher relationships, there were lower associations with the probability and frequency of subsequent behavioural problems and violent actions. This means that the nature of teacher-student interaction can directly affect students' behavioural and emotional engagement. When teachers support and interact positively with students, then students are more likely to be engaged and behaved 
appropriately. Institutional administrators therefore should establish a disciplined school environment for positive interactions that can enhance a culture of peace.

Orderly behaviour among staff and students and a favourable learning environment are two of the numerous advantages of effective communication in school. This orderly behaviour among members of the school organization is termed discipline. If a culture of peace is to be enhanced in school, there must be effective maintenance of discipline. This is an onerous task of the institutional administrator. Therefore, in school, discipline should not only be seen as an instrument for success in administration, but also as a means of promoting peace culture. Adesina (1990) referred to school discipline when students are taught to respect the school authorities, to observe the school laws and regulations and to maintain an established standard of behavior. Discipline as a component of organizational climate is viewed by Aghenta and Omoregie (2006) as behavior which involves such characteristics as self sacrifice, diligence, cooperation, integrity, truthfulness, patriotism, consideration for others, trust, sympathy and respect. Thus, discipline is the maintenance of the quality of the atmosphere necessary for the achievement of school goals. Kohn (1996) in his study reported that discipline should be seen as involving socialization and this can be achieved by the school administrator by providing a positive school climate for the subordinates to ensure the expression of good behaviour and attitudes that can promote a culture of peace. Asagwara (1992) reported that discipline involves the orderly performance of activities and good behaviour which take into account honesty and healthy social interactions. This means that the school administrator should establish a stimulating school climate that is welcoming, accompanied by adequate communication with staff, students and parents. This would foster sustainable peace culture in school. Ezeocha (1985) in his study reported that discipline should recognize the inherent dignity and rights of everyone, be devoted to humanitarian principle and ideals, offer self-direction and be founded on understanding of acceptable goals on which to base appropriate behaviour

Building a culture of peace in higher institutions through effective management of school climate is posited as a process that enables the practice of dialogue and participation in democratic structures to work as tools for change, for achieving deep transformation and for promoting peace (Al-Smadi, AbuQudaus \& Manhasbeh, 2010). Osman (2012) in his work reported that communication adequacy in organizations was a necessary requirement for promoting peace culture. Therefore, there should be open communication and transparency if peace is to reign in our institutions of higher learning. Communication should be relatively distortion-free. Communication should be vertically, horizontally and across the boundary of the institution to and from the surrounding environment. According to Sergiovanni and Starrat (1998), this type of communication makes people to have information they need without exerting undue efforts. Research by Stronge and Jones (1991) showed that effective and open communication enhanced a peaceful atmosphere in school and this enable both teachers and students to discharge their responsibilities effectively.

Oreiden (2006) described school climate as embracing both the physical and social structures of the school with which much concern is on the administrator who saw to the management and coordination of both human and material resources. The physical setting has to do with the appearance and physical structures of the school which must be effectively managed to provide a congenial teaching and learning environment. Researchers have shown that many of the violent demonstrations by students and strikes by lecturers in higher institutions occurred as a result of the poor state of infrastructural facilities (Ngurukwem, 2000; Ikwuazon, 2000; Ololobou, 2007 \&Akpan, 2001). Cornell, Gregory and Fan (2011) reported in their study that the physical environment of the school significantly influenced students' attitude toward a culture of peace. This means that the way students perceive the physical environment of the school, would affect their cultivation of a culture of peace.

\section{Research Methodology}

\subsection{Research Design}

The survey research design was adopted for the study. This design was considered suitable because it made comparison and evaluation of existing conditions as well as collection of factual information through the use of a questionnaire.

\subsection{Population and Sample}

The population of the study consisted of 2,415 teachers from 4 higher institutions in the study area. The institutions used were University of Calabar, Cross River University of Technology, College of Education, Akamkpa and Federal college of Education, Obudu. Simple random sampling technique was used to select a sample of 500 lecturers for the study. The sample consisted of 200 lecturers from University of Calabar, 100 lecturers from Cross River University of Technology and 75 lecturers each from Federal College of Education, Obudu and College of Education, Akamkpa respectively. 


\subsection{Research Instrument}

The instrument for data collection was a questionnaire titled "Organizational Climate and Sustainable Peace Culture Questionnaire (OCSPCQ)" for lecturers. The instrument consisted of 3 sections. Section A sought personal information about the respondents such as gender, age, rank, qualification etc. Section B consisted of 25 items that measured 5 sub variables of organizational climate namely, Leadership (5 items), Communication (5 items), Physical facilities (5 items), Discipline (5 items) and interpersonal relationship (5 items). Section C consisted of 10 items that measure sustainable peace culture. The instrument was a 4-point response scale. Each item on the instrument had 4 response options ranging from Strongly Agree (SA), Agree (A) to Disagree (D) and Strongly Disagree (SD). The respondents were required to tick one option against an item to indicate the extent of their agreement or disagreement with the item. The reliability coefficient of the instrument was 0.86 , using Cronbach reliability method. This was high enough for the instrument to be considered reliable. The instrument was administered on the respondents in their various institutions with the help of 4 research assistants. Copies of the instrument were filled and returned on the spot. All the 500 copies of the questionnaire administered were correctly filled and returned.

\section{Data Analysis and Results}

The statistical technique used for data analysis was multiple regressions. This was used to find out the combined relative contributions of the 5 components of organizational climate to the prediction of sustainable peace culture in higher institutions.

$\mathrm{HO}_{1}$ : Organizational climate does not significantly predict sustainable peace culture in higher institutions. The subvariables of organizational climate used in this study included leadership, communication network, physical facilities, discipline and interpersonal relationship. The dependent variable was sustainable peace culture. The result of multiple regression analysis is presented on Table 1.

Table 1: Summary of multiple regressions of the predictor variables on sustainable peace culture in higher institutions

\begin{tabular}{lccccc}
\hline Multiple $\mathrm{R}$ & $=$ & 0.675 & & & \\
$\begin{array}{l}\text { Multiple } \mathrm{R}^{2} \\
\text { Standard Error }\end{array}$ & $=$ & 0.456 & & & \\
\hline Source of Variance & & $\mathrm{Ss}$ & $\mathrm{df}$ & $\mathrm{Ms}$ & $\mathrm{F}$ \\
\hline Regression & 8621.15 & 5 & 1724.23 & \\
& & & & & \\
Residual & 81618.68 & 494 & 165.22 & \\
Total & 90239.83 & 499 & & \\
${ }^{*} \mathrm{p}<.05 ; \mathrm{df}=5$ and 494; Critical-F $=3.02$. & & & \\
\hline
\end{tabular}

Table 1 reveals a positive significant relationship between the joint predictor variables of organizational climate (Leadership, Communication, Physical facilities, Discipline and Inter-personal relationship) and sustainable peace culture in higher institutions $(r=0.675 ; p<.05)$. The multiple $R^{2}$ value of 0.456 depicts that $45.60 \%$ of the variance in determinacy of sustainable peace culture in higher institutions is accounted for by organizational climate. The result of analysis of variance gave an F-value of 10.44. This was found to be greater than the critical F-value of 3.02 needed for significance at 0.05 level of significance with 5 and 494 degrees of freedom. This means that the sub-variables of organizational climate jointly and significantly predict sustainable peace culture in higher institutions. With this result, the null hypothesis is rejected.

$\mathrm{HO}_{2}$ : There is no significant relative contribution of each of the components of organizational climate to sustainable peace culture in higher institutions.

The result of data analysis is presented on Table 2. 
Table 2: Relative contributions of organizational variables to sustainable peace culture in higher institutions

\begin{tabular}{llllll}
\hline $\begin{array}{l}\text { Organizational } \\
\text { climate variables }\end{array}$ & $\mathrm{B}$ & \multicolumn{1}{l}{ SE } & \multicolumn{1}{l}{ Beta } & T-ratio \\
\hline 1. & Leadership & 0.125 & 0.053 & 0.129 & $2.435^{*}$ \\
2. & Communication & 0.130 & 0.045 & 0.127 & $2.706^{*}$ \\
3. Physical facilities & 0.126 & 0.058 & 0.112 & $2.257^{*}$ \\
4. $\quad \begin{array}{l}\text { Discipline } \\
\text { 5. Interpersonal }\end{array}$ & 0.134 & 0.049 & 0.140 & $3.082^{*}$ \\
& relationship. & 0.163 & 0.064 & 0.150 & $3.651^{*}$ \\
\hline
\end{tabular}

${ }^{*} \mathrm{p}<.05 ;$ Constant $=9.345$

Table 2 shows for each component of organizational climate unstandardized regression coefficient (B), Standard Error (SE), Standardized Coefficient (Beta) and T-ratios. Thus, table 2 reveals that Inter-personal relationship $(t=3.651 ; p<$ $.05)$, Discipline $(t=3.082 ; p<.05)$, Communication pattern $(t=2.706 ; p<.05)$, Leadership $(t=2.435 ; p<.05)$ and Physical facilities $(t=2.257 ; p<.05)$ in that order, relatively make significant contributions to the prediction of sustainable peace culture in higher institutions. The findings reveal that interpersonal relationship is the most potent predictor of sustainable peace culture and physical facilities, the least.

\section{Discussion of Findings}

The finding of this study reveals that organizational climate variables when joined together significantly predict sustainable peace culture in higher institutions. This means that sustainable peace culture in higher institutions does not happen by chance. One of the findings reveals that interpersonal relationship is the most potent predictor and physical facilities the least. This research finding could be attributed to the fact that administrators of the institutions used for this study have realized the need to effectively manage the school climate variables for enhancement of sustainable peace culture. Interpersonal relationship being the most potent predictor depicts that there is a cordial and healthy interpersonal relationship between staff and management, among staff and between staff and students. Of course, this could be linked to the leadership style of the administrators and their ability to use open communication and participative management. The present finding is in consonance with the work of Sweeney (1992) who reported that the level of interpersonal relationship significantly influenced sustainable peace culture in any work organization. The present finding is also in agreement with the research finding of Merger-Adam and Conner (2008) which showed that a healthy organizational climate influenced teachers' and students' attitude towards a culture of peace.

The finding of the study also shows that discipline relatively contributes to sustainable peace culture in higher institutions. This means that discipline as a component of school climate is a potent factor for sustainable peace culture in schools. The finding depicts that there is relative peace in institutions of higher learning in recent times probably due to the administrators' efficiency in managing staff's and students' discipline. Effective management of discipline reduces conflict and enhances non-violent actions. It also enhances healthy social interactions. This finding agrees with the work of Kohn (1996) who reported in his study that discipline involves socialization and this can be achieved by the administrator providing a positive school climate for the subordinates to ensure the expression of good behaviour and attitude that can promote a culture of peace.

A third finding of this study shows that communication significantly predicts sustainable peace culture in higher institutions. This means that communication is an important variable of organizational climate that can enhance a culture of peace in higher institutions. Effective communication in work organizations creates an atmosphere of peace and eliminates rumours and gossips. Effective communication enables both staff and students to know and do what is expected of them in order to achieve the goals and objectives of their institutions. This finding is in agreement with the research work of Stronge and Jones (1991) who found out that effective and open communication enhanced a peaceful atmosphere in school and this enabled both teachers and students to discharge their responsibilities effectively.

The present study also reveals that leadership significantly contributes to the prediction of sustainable peace culture in higher institutions. This finding could be attributed to the effective leadership of institutional administrators. This finding depicts that the promotion of a culture of peace in higher institutions depends to a large extent on the leadership styles of administrators. Administrators of the institutions used for this study must have seen the need to utilize participative leadership styles which make members of the school community to have a sense of belonging. The way staff and students feel about the school and themselves is a direct result of the leadership styles. The leadership style 
therefore, has a significant role to play on the quality of attitudes of organizational members, their mutual relations and interactions as well as in creating a peaceful working environment and harmony for effective job performance (Taymaz, 2003). This finding agrees with the work of Osman (2012) who reported a significant correlation between leadership as a component of school climate and a culture of peace in school. The research finding of Remondini (2001) also lends credence to the present finding. The researcher reported that a significant relationship existed between leadership styles and organizational climate for supportive principal behaviour and intimate teacher behaviour. This means that leadership style can influence the behaviour and attitude of school administrators, teachers and students toward sustainable peace culture.

The study also reveals that physical facilities as a component of school climate significantly predict sustainable peace culture in higher institutions. This means that peaceful behaviour among students and teachers in higher institutions can be promoted through the provision and effective management of infrastructural facilities. Thus, peaceful behaviour is a learnt behaviour that can be enhanced by effective management of the school physical environment.

Therefore, if adequate school facilities such as instructional materials, libraries, lecture halls with seats, office accommodation for staff, equipment, recreational facilities, modern technological facilities are provided and properly managed to aid teaching and learning, violence actions and strikes by both students and staff can be abated. This will encourage good behaviour and attitude that can promote a culture of peace. Ikwuazon (2000) and Ololobou (2007) reported in their studies that many of the violent demonstrations by students and strike actions by lecturers occurred as a result of the poor state of infrastructural facilities in higher institutions. The finding of this study is in agreement with the research finding of Cornell, Gregory and Fan (2011) who reported that physical environment of the school significantly influenced students' attitude toward a culture of peace.

\section{Conclusion}

Premised on the findings of this study it could be concluded that organizational climate variables namely interpersonal relationship, discipline, communication pattern, leadership and physical facilities are significant predictors of sustainable peace culture in higher institutions in Cross River State of Nigeria. This shows that organizational climate can be used to explain and predict the existence of a culture of peace in higher institutions. Thus, the way the institutional administrators manage the various aspects of organizational climate to that extent will a peace culture be sustained in the institutions.

\section{Recommendations}

It is recommended that:

Institutional administrators should encourage a healthy interpersonal relationship in higher institutions as this has been found to greatly predict sustainable peace culture.

Administrators should create a disciplined school environment. They should be embodiments of discipline in order to serve as models for staff and students. Self-discipline should be encouraged.

Both the government and institutional administrators should intensify efforts to provide adequate and quality facilities in higher institutions. The facilities should be effectively managed to keep them functional for use by both staff and students. This will reduce the incidence of violence among students.

Institutional administrators should reconsider their leadership styles. Democratic and transformational leadership styles should be embraced. Both staff and students should be given opportunities to participate in decision making particularly decisions that would affect them. This will make them to have a feel of the organization and cultivate a positive attitude toward a culture of peace.

Institutional administrators should practice open communication. There should be free flow of information. Open communication checks rumours and gossips among staff and students and develop in them a positive attitude that can enhance a culture of peace.

\section{References}

Adesina, S (1990). Educational Management. Enugu: Fourth Dimension.

Aghenta, J. A \& Omoregie, E. O. (2006). Fundamentals of Educational Management. Agbor, Delta State, Nigeria. KRISBEC publications. Akpan, C. P. (2001). Strategies for sustainable management of school physical facilities in the $21^{\text {st }}$ Century.International Journal of Educational Administration, Planning and Research. 1(1), 125-135.

Aksu, A. (1994). Effectiveness of School Managers and School Climate. Nonu universities, SOSyalBihin or Enstitusu. 
Al-Smadi, R. T., AbuQudous M. \& Mashasneh (2010). Academic Administrators making a difference: Promoting Peace Education in Jordanian Higher Education. International Journal of Applied Educational Studies.9(1), 67-77.

Asagwara, C.G. (1992). Discipline in primary schools: Essence, Practice and Procedure. In H. J. Nenty and T. N Ekpo (eds.).Effective Management and Administration of Primary Schools.(pp 55-61) Eket: Ememobong Publishers.

Berkowitz, M. W. \& Bier, M. C. (2006). What works in character Education. A report for policy Makers and Opinion leaders. Retrieved June 20, 2015 from http://www.characterandcitizenship.org.research.

Rivera, D. J. (2009).Building Cultures of Peace that Protect Human Rights. Retrieved July 15, 2015 from http://www.haguepeace.org.

EDUCA Peace Education Project (2003).Building and Sustaining a Culture of Peace in the School-community.RetrievedMay3, 2015 from http:// www.haguepeace.org.

Ezeocha, P. A. (1990). Educational Administration: Concepts and Cases. Oweri: Pacyic Publishers.

Forehand, G. A. (1968). On the interaction of persons and organizations. In R. Taguin and G. H. Litwin (eds.). Organizational Climate.(pp. 101-120) Boston: Havrard University, Division of Research.

Furman, G. \& Grunewald, A.(2004). Expanding the Landscape of social justice. A critical ecological analysis. Educational Administration Quarterly. 40(1), 47-76.

Goldstein, S. E., Young, A. \& Boyd, C. (2008). Relationship of aggression at school Association with school safety and social climate. Journal of Youth and Adolescence. 37(6), 641-654.

Gonder, P. O. \& Hymes, D. (1994).Improving school climate and culture. American Association of School Administrators (AASA).Critical Issues Report, No. 27, Arlington, VA.

Gregory, A., Cornell, D. \& Fan, X. (2011). Relationship of school structure and support to suspension rates of black and white high school students. American Educational Research Journal.48(4), 904-934.

Gul in, H. (2008).Organizational Climate and Academic Staff Perception on Climate Factors. Humanity and Social Science Journal. 3(1), 37-48.

Howard, E., Howell, B. \& Brainard, E., (1987).Handbook for conducting School Climate Improvement Projects. Bloomington, Indiana: Phi delta Kappa Educational Foundations.

Ikwuazom, A. C. O. (2000). Strategies for the provision of enabling environment for the retention of UBE Teachers. International Journal of Research in Basic \& Life-Long Education. 1(1 \& 2), 433-438.

Karcher, M. I. (2002). The cycle of violence and disconnection among rural middle school students. Teachers' disconnectedness as a consequence of violence. Journal of school violence.1(1), 35-51.

Kohn, A. (1996). Beyond Discipline: From Compliance to Community. Alexandaria VA. Association of Supervision and curriculum Development.

Likert, R. \& Likert, J. G. (1976).New ways of managing conflict. New York: McGraw Hill.

Merge-Adams, N.\& Conner, B. L. (2008). School Violence: Bullying behaviour and the Psychosocial school environment in middle schools. Children and School. 30(4), 211-221.

Ngurukwem, E. C. (2000). Resource Audit: A Pre-requisite for adequate resourcing of Universal Basic Education Scheme in Nigeria. International Journal of Research in Basic and Life-Long Education. 1(1 \& 2), 136-143.

Oke, I. (2006). Conceptualizing Peace. In S.G. Best (Ed). Introduction to peace and conflict studies in West Africa. Ibadan: Spectrum Books.

Ololobou, C. O. (2007). Challenges in Teacher Preparation Efforts in Colleges of Education. The way forward. Journal of Curriculum Studies. 14(3), 299-306.

Oredein, A. O. (2006). Transformational Leadership and School Climate as Determinants of Secondary School Teachers' Institutional Commitment in Ogun State. Nigeria Journal of Sociology and Education in Africa.5(1), 31-48.

Osman, A. A. (2012). School Climate: The key to Excellence. Journal of Emerging Trends in Educational Research and Policy Studies. 3(6), 950-954. Retrieved March 13, 2015 from http://www.jeteraps.schoolarlinkresearch.org.

Peretomode, V. F. (1999). Educational Administration: Applied Concepts and Theoretical Perspective for students and Practitioners. Nigeria: Joja Educational Research and Publishers.

Remondini, B. (2001) Leadership style and school climate: A comparison between Hispanic and non-Hispanic within principals in Southern New Mexico. Doctoral Dissertation, New Mexico State University.

Sergioranni, T. J. \& Starratl, R. J. (1998). Supervision: Redefinition. Boston: M. A. McGraw

Shields, C. (2004). Dialogic Leadership for social justice: Overcoming Pathologies of silence. Educational Administration Quarterly. 40(1), 109-132.

Stronge, J. H \& Jones, C. W. (1991). Middle school climate: The principal role in Influencing Effectiveness. Middle School Journal. 22(5) 41-45.

Sweeney, J. (1992). School climate: The key to Excellence. NASS Bulletin 76(54), 69-73.

Taymaz, H. (2003). School Management. Ankara: Pegen A Yayinev Tic.

Wang, M. E., Seliman, R. I., Dishion, I.I \& Stormshark, F. A. (2010).A Tobit Regression analysis of the co-variation between middle school students' perceived school climate and behavioural problems. Journal of Research on Adolescence. 20, 274-286.

Western Alliance for the study of school climate (no date).Introduction to assessment at WASSC. Retrieved September 30, 2014 from http://www.casttela.edu/centers/schoolclimate/assessment.html. 